\title{
Bilingual Educational Policy in Georgia: Can it Benefit the Process of the Integration of Society?
}

Shalva TABATADZE ${ }^{1}$

$\approx$ This article reviews the educational policy for the integration of society in Georgia. It is an analytical research paper on the current situation of ethnic minority education in Georgia. The problems and opportunities of bilingual education policy are analysed in the article. The content analysis research method was utilised in the study. The author argues that bilingual education is a crucial tool for the integration of Georgian society; however, local control, involvement, and context are crucial in the implementation of a national bilingual educational programme. The changes on the political, institutional and pedagogical levels of bilingual education are necessary for the successful implementation of bilingual education reform.

Keywords: bilingual education, ethnic minorities, non-Georgian language schools, Georgia 


\section{Ali lahko politika dvojezičnega izobraževanja v Gruziji prispeva $\mathrm{k}$ integracijskim procesom $\mathrm{v}$ družbi?}

Shalva TABATADZE

$\propto$ Članek obravnava izobraževalno politiko za integracijo družbe v Gruziji. Gre za analitični znanstveni članek o trenutnem stanju izobraževanja etničnih manjšin v Gruziji. V njem so analizirane težave in priložnosti dvojezične izobraževalne politike. $\mathrm{V}$ raziskavi je bila uporabljena raziskovalna metoda, ki zajema analizo vsebine. Avtor trdi, da je dvojezično izobraževanje ključno orodje za integracijo gruzijske družbe, čeprav so lokalni nadzor, vključenost in kontekst ključnega pomena pri implementiranju nacionalnega dvojezičnega izobraževalnega programa. Za uspešno izvajanje dvojezične reforme izobraževanja so nujne spremembe na politični, institucionalni in na pedagoški ravni.

Ključne besede: dvojezično izobraževanje, etnične manjšine, negruzijske (tuje) jezikovne šole 


\section{Introduction}

Bilingual education policy is an essential issue for multi-ethnic states. Every multi-ethnic state attempt to implement appropriate educational policy that will enable it to solve the issue of minorities' education and their integration in the state's economic, political and social life. The political, economic, civil and social participation of ethnic minorities is a primary goal of all democratic state policies. However, the instruments, strategies, policies, and values to achieve this goal are different for different countries and even more different within the country, based on political, locational and situational contexts.

The research findings on the effects of bilingual education on children's language awareness and cognitive functioning are mostly positive (Bekerman, 2005). The effects are summarised by Skugtnabb-Kangas and Garcia (1995): (1) competence in at least two languages; (2) equal opportunity for academic achievement; (3) cross-cultural and positive attitudes toward self and others. Despite the encouraging research findings and proved benefits of bilingual education, it remains a controversial and misunderstood field in educational policy (Bekerman, 2005).

Based on existing research studies, this analytical article reviews the educational policy for the integration of ethnic minorities into the Georgian mainstream. The first section underlines the importance of bilingual education based on the political, demographic, and educational context of Georgia. The second section analyses the problems of bilingual educational policy in Georgian reality. The third discusses the possibilities of promoting the implementation of proper bilingual educational policy. The author argues that bilingual education is a crucial tool for the integration of ethnic minorities; however, political, structural, institutional, and pedagogical changes are necessary to have the benefits and the positive effect of bilingual education.

\section{Georgian Context for Bilingual Education}

\section{Diversity of Georgia}

Every educational policy needs its political context to be started and implemented (San Miguel, 2003). This is true, then, of the political context for the bilingual educational policy of Georgia, which is a multi-ethnic country with 3.7 million inhabitants. According to the 2014 census, ethnic Georgians account for $86.8 \%$ of the total population, and ethnic minorities are $13.2 \%$ of it (Gorgadze, 2016; State census, 2014). Ethnic minorities are compactly settled in 
four regions of Georgia: Abkhazia, South Ossetia (Shida Kartli), Kvemo Kartli and Samtskhe-Javakheti. Kists are settled in Kakheti (including the Pankisi Valley), but in total, they comprise only $7 \%$ of the region's population. Apart from compact settlements, ethnic minority groups are settled in different territories of the country. These groups are Russians, Greeks, Kurds and/or Yezidis, Assyrians, Jews, Ukrainians, Armenians and Azerbaijanis (Beridze, 2013; Gabunia, 2014; Svanidze, 2002; Tabatadze, 2016).

\section{The Soviet heritage and the collapse of the Soviet Union}

Georgia gained independence in 1991 after the collapse of the Soviet Union. Communist policies of forced migration have engendered difficult multilingual problems in the former Soviet Union countries (Hogan-Brun \& Ramonlene, 2004). The language of communication of ethnic groups between and within the republics was Russian during the Soviet Era. As a result of Soviet educational and language policy, the residents of the Republic of Georgia with a different ethnic origin (Russians, Armenians, Azerbaijanis, Abkhazians, Ossetians, Greeks, Kurds, and others) became members of the Russian political and language society.

Post-Soviet republics have been implementing new language and educational policies since 1991. Pavlenko (2008) emphasises several challenging factors for the implementation of an educational language policy in post-Soviet area: (1) large number of Russian speakers; (2) Russification of dominant cultural groups in former republics of the former Soviet Union; (3) working with non-integrated ethnic minority groups; and (4) functional limitations of some of the languages of dominant cultural groups in post-Soviet republics. Based on these challenges, the republics of the former Soviet Union started with language policy reforms in the educational system. Three main policy directions can categorise these reforms: (1) bilingual education to strengthen the knowledge of the state language in minority groups; (2) substitution of Russian language with the language of dominant cultural groups; and (3) bilingual education to respond to the functional limitation of languages of dominant cultural groups and empower this language while supporting functioning in the Russian language. There are significant directions absent in these bilingual educational reforms, including designing and implementing bilingual educational programmes to support minorities' education in their native language in schools with state language instruction, implementing bilingual education programmes for dominant cultural groups to learn minority languages in the regions of compact settlements of ethnic minorities, and implementing bilingual 
education reform based on the foreign policy of the countries.

Georgia used the experience of Latvia during the initial design and implementation of bilingual education reform. Latvian specialists, as well as various governmental and non-governmental organisations, actively cooperated with both the Ministry of Education and Science of Georgia and other stakeholders (Grigule, 2009). The Latvian experience was significant and, accordingly, it is necessary to provide an overview of bilingual educational reform in Latvia, with its shortcomings and successes. The educational reform in Latvia mostly focused on reforming Russian schools and increasing facilitation of the teaching of the Latvian language in the Russian-speaking population. Unlike too many bilingual educational reforms worldwide, in Latvia, the objective of minority educational reform was not supportive of minority languages (Batelaan, 2002).

Bilingual educational reform in Latvia started in primary school in 1999 and secondary school in 2004 (Kḷava, Kḷave, \& Motivāne, 2010). Four different models were developed for bilingual educational programmes in the primary schools of Latvia. In all four types of programmes, there were certain amounts of hours allocated for Latvian and the native languages of minority groups (Dilāns \& Zepa, 2015). Minority schools could select from amongst four different types of bilingual education programmes. The results and effects of bilingual educational programmes are controversial. As Dilāns and Zepa (2015) stated: '[The] Latvian case shows that the implementation of the four types of bilingual education was criticised for its authoritarian nature, the lack of readiness among minority school teachers, the lack of information among policy participants and target audiences.' (p. 640). At the same time, many researchers agree that bilingual educational reform achieved 'the improvement of Latvian language skills among minority students and enhanced competitiveness in higher education and the labor market' (Kḷava, Kḷave, \& Motivāne, 2010 as cited in Dilāns \& Zepa, 2015, p. 641).

Like other post-Soviet countries, the collapse of the Soviet Union and independence required that Georgia build a language policy in an educational system as well as to develop a new strategy toward ethnic minorities.

\section{The educational system and the challenges of quality education in minority schools}

The educational system in Georgia comprises preschool, general, and tertiary education, as well as secondary vocational education and training. General education is offered at three levels: primary education (grades 1 to 
6), basic education (grades 7 to 9), and secondary education (grades 10 to 12 ). There are 2,084 public and 230 private schools in Georgia with approximately 560,00o students (Tabatadze \& Gorgadze, 2014).

Article 4 of the Law on General Education of Georgia states that 'citizens for whom Georgian is not a native language have the right to acquire general education in their native language'. According to data from 2013, there are currently 213 non-Georgian language schools and 77 non-Georgian language sectors in Georgia (Tabatadze, 2015a):

\section{Table 1}

Non-Georgian language public schools by region, developed from the data of Ministry of Education and Science of Georgia, 2013

\begin{tabular}{lcccc}
\hline Region & Azerbaijani & Russian & Armenian & Total \\
\hline Adjara & 1 & 2 & 1 & 0 \\
Tbilisi & & & 4 \\
$\begin{array}{l}\text { Imereti } \\
\text { Kakheti }\end{array}$ & 4 & 1 & & 5 \\
Samegrelo- Upper Svaneti & & & & \\
Samtskhe- Javakheti & & 4 & 96 & 100 \\
Kvemo Kartli & 80 & 4 & 20 & 104 \\
\hline Total & 85 & 11 & 117 & 213 \\
\hline
\end{tabular}

Statistical data about the ethnic minorities' integration into the Georgian mainstream reveal a dire situation. For example:

(1) The enrolment of ethnic minorities in higher education is very low (Tabatadze \& Gorgadze, 2016);

(2) The number of ethnic minorities failing the Unified National Exams for University entrants is very high. Those who did not fail received the lowest grades at the test;

(3) The dropout rates are the highest in minority students at higher educational institutions. For example, $14,7 \%$ of ethnic minority students enrolled at Tbilisi State University in 2010 completed undergraduate studies in 2015 (Tabatadze \& Gorgadze, 2016);

(4) The representations of ethnic minorities in the central and local legislative, executive or judicial branches of government are very low (Office of the State Minister of Georgia for Reconciliation and Civil Equality 2014); 
(5) The number of failing students in school exit exams from non-Georgian language schools is below the average countrywide results. For example, approximately $29 \%$ of the non-Georgian language schools graduates from compact settlements failed in the physics school exam, while the average number of failed students is $4 \%$ countrywide (Tabatadze, 2016);

(6) The Programme for International Students Assessment (PISA) 2009 confirms the problems of ethnic minority students in literacy, math, and science in comparison to their Georgian counterparts. According to the PISA 2009 results, the Georgian students have low results in reading, math and science compared to international averages; however, the results of minority students are even lower in comparison to those of their Georgian counterparts (Tabatadze, 2016).

The statistical data and research results mentioned above directly indicate the inefficiency of non-Georgian schools. These schools are the direct heritage of the Soviet educational system. The Georgian government started to reform these schools, specifically:

(1) On December 15, 2010, amendments were made to the Law on General Education; multilingual education was defined as 'education, which aims to develop a student's linguistic competence and understanding in a variety of languages...' (Law on General Education, 2005);

(2) The Georgian government adopted the policy goal of implementing multilingual education (MLE) reform in 2009. MLE policy has been included in the action plan and concept on 'Tolerance and Civil Integration of the Government of Georgia';

(3) Multilingual Educational Programme Regulations were adopted by the Ministry of Education and Science of Georgia (MoES) in 2010;

(4) A professional standard of teachers of Georgian as a second language was adopted in 2010;

(5) MoES of Georgia adopted bilingual teacher standard in 2012 (Tabatadze, 2015 b).

\section{Research Methodology}

The study explored the existing situation of bilingual educational reform of Georgia. In analysing the content of the study, a qualitative research method was utilised. The following approaches were used for content analysis: (1) study of the legislation in the field of bilingual education in Georgia; (2) study of existing research on minority education in Georgia; (3) review of statistical 
data on minority education in Georgia. The present study poses the following research question: What political, institutional and pedagogical aspects of bilingual education have to be changed for the successful implementation of bilingual education reform in Georgia?

\section{Research Results}

\section{The problems of the implementation of bilingual educational policy in Georgia}

The content analysis demonstrated important factors on different levels that affect the effective implementation of bilingual educational reform. The problems impacting such policy can be divided into two parts: (1) political and structural issues, and (2) institutional/pedagogical issues. Both will be briefly reviewed below

\section{Political/Structural challenges for bilingual educational reform}

Political problems of bilingual educational policy in Georgia have several fundamental reasons. It is necessary to understand the differences in the political context of bilingual education in Georgia and, for example, in the United States, where bilingual education was part of the civil rights movement of the 1960s, and demand for bilingual education came from the civil rights leaders of representatives of ethnic minorities (Crawford, 2000). In Georgia, the initiative for bilingual educational comes from the government, and it is mainly perceived as a violation of the educational rights of ethnic minorities by their representatives (Kurbanov, 2007). As mentioned earlier, we can describe the ethnic minorities of Georgia as 'Involuntary Minorities'. As John Ogbu points out, it is not unusual for these groups to engage in so-called cultural inversion, that is, to resist becoming integrated into the dominant culture. Instead, involuntary minorities can be engaged in oppositional behaviour, encouraging behaviours that are different and in opposition to the majority culture (Giroux, 1983; Ogbu, 1987). Thus, the problems of bilingual educational policy can be highly complex in the Georgian context and refusing to learn the Georgian language and study in bilingual schools can become a form of political resistance on the part of ethnic minorities.

One problem with planning minority educational policy is that it focuses on teaching the state language rather than reforming minority schools and improving the quality of education in them. The real concern, often ignored, 
is the general quality of education in non-Georgian schools, which can have a significant impact on the teaching of the state language. Policy documents do not focus on non-Georgian language school reform that improves the overall quality of education (Monitoring Reports of Public Defender of Georgia 2010, 2011, 2012, 2013; Office of the State Minister of Georgia for Reconciliation and Civil Equality, 2014; Strategy on Tolerance and Civil Integration of Government of Georgia 2009-2014; Strategy on Tolerance and Civil Integration of Government of Georgia 2015-2020).

Inconsistencies in bilingual education reform are a significant barrier to the effective implementation of bilingual educational programmes (Ministry of Reconciliation and Civil Equality, 2014). The leadership of the Ministry of Education and Science constantly changes, with nine ministers between 2008 and today. The absence of 'heritage' in policy implementation is characteristic of political reform in Georgia; even members of the same ruling parties change the policy directions of their previous colleagues. As a result, the bilingual education reform started in 2009 was completely discontinued in 2011, and almost the entire burden of reform shifted to bilingual textbooks (Office of the State Minister of Georgia for Reconciliation and Civil Equality, 2014). Accordingly, the ministry failed to establish bilingual education reform that could be implemented consistently and realised fully.

\section{Institutional problems for bilingual educational reform}

The institutional problems are significant as well, which implies how teachers and schools care for students and how the lack of resources for bilingual education will be overcome by the state and schools (Nieto, 2005). There are several problems on the institutional level, but the most urgent is the lack of human resources and textbooks, which seems to be the most crucial and problematic in Georgian context (Monitoring Reports of Public Defender of Georgia 2010, 2011, 2012, 2013; Office of the State Minister of Georgia for Reconciliation and Civil Equality, 2014).

\section{Teacher's qualification}

The problems of teacher professional development persist in non-Georgian language schools. Tabatadze and Gorgadze (2015) identified the most pressing and challenging issues of teachers' qualification in non-Georgian language schools, specifically: First, both private providers and the Teacher's House only conduct professional development programmes in the state language. 
Accordingly, these programmes are not available to teachers of non-Georgian language schools, as the number of teachers speaking the state language in regions densely populated by ethnic/national minorities is very low (Office of the State Minister of Georgia for Reconciliation and Civil Equality, 2014). Second, the certification exam is only administered in the state language, and teachers of nonGeorgian language schools are deprived of the right to pass exams in their native language. They are unable to use the benefits associated with the certification. The existing statistical data clearly demonstrates the low level of accomplishment in certification for non-Georgian-speaking teachers since most of them were not able to pass the certification exam (Tabatadze \& Gorgadze, 2015).

Table 2

Certified teachers of non-Georgian language schools (Except language teachers)

\begin{tabular}{lccccc}
\hline City & $\mathbf{2 0 1 3}$ & $\mathbf{2 0 1 2}$ & $\mathbf{2 0 1 1}$ & $\mathbf{2 0 1 0}$ & Total \\
\hline Akhaltsikhe & 0 & 0 & 1 & 0 & 1 \\
Gardabani & 2 & 1 & 0 & 0 & 3 \\
Dmanisi & 0 & 1 & 0 & 0 & 1 \\
Bolnisi & 1 & 1 & 0 & 0 & 2 \\
Marneuli & 9 & 0 & 1 & 0 & 10 \\
Rustavi & 0 & 4 & 3 & 1 & 8 \\
Tsalka & 0 & 1 & 0 & 0 & 1 \\
Akhalkalaki & 8 & 0 & 0 & 0 & 8 \\
Ninotsminda & 3 & 0 & 0 & 0 & 3 \\
\hline Total & $\mathbf{2 3}$ & $\mathbf{8}$ & $\mathbf{5}$ & $\mathbf{1}$ & $\mathbf{3 7}$ \\
\hline
\end{tabular}

The number of those registered for the certification exam is numerically very low in relation to the number of teachers in these schools. It should also be noted that only $5 \%$ were able to pass the exam and acquire the status of teacher. Only 37 out of 6830 teachers from densely settled regions were certified in 2010-2013 (Tabatadze \& Gorgadze, 2015). The statistical charts showcased above clearly demonstrate the problems existing with the certification of nonGeorgian-language teachers.

Teachers of Armenian and Azerbaijani as native languages do not have the opportunity for professional development, or certification, which, on the one hand, has a negative effect on the quality of education in non-Georgian language schools and, on the other hand, is discriminatory towards the teachers of these subjects. They do not have the opportunity to benefit from the teacher certifications or other social benefits 
Teachers in non-Georgian language schools are, on average, older than their Georgian counterparts. There 6830 teachers in non-Georgian language schools (Tabatadze \& Gorgadze, 2015). Sixty per cent of the teachers in nonGeorgian language schools are over 46 years old while $24.1 \%$ are over 61 years old. This means that most of them will have to be replaced during the next 20 years. The chart below clearly illustrates the problem of the ageing of nonGeorgian-language school teachers.

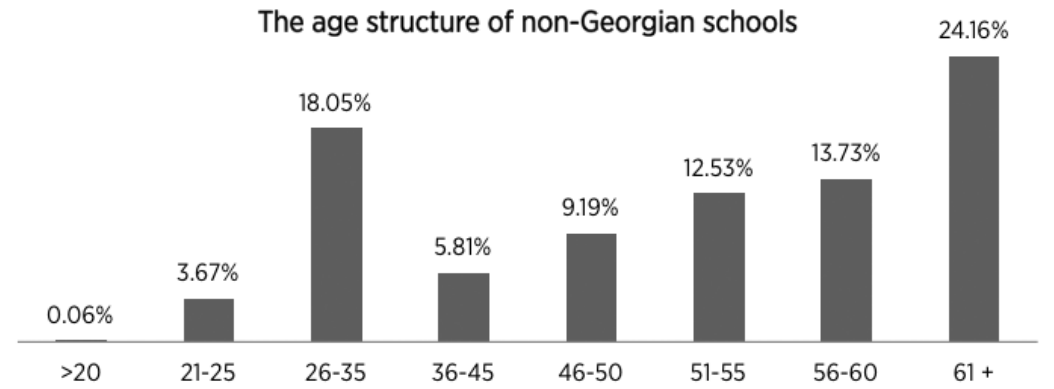

Figure 1. The Age Structure of Teachers in Non-Georgian Language Schools.

\section{Qualification of school principals}

According to the official results of the professional examinations provided by the Ministry of Education and Science, only eleven out of 175 candidates from Javakheti public schools managed to pass the test, eight of them being ethnic Georgians. In Kvemo Kartli, out of 659 candidates, 273 managed to pass the exam, but only eight of them were ethnic Azeris. In total, in Georgia, there were 5,197 candidates for the school principal tests in 2007 with 3,427 candidates successfully passing the test (Mekhuzle \& Roche, 2009). Non-Georgian language schools faced a serious problem because the number of candidates nominated to direct each of them was insufficient. The number of nominations for non-Georgian language schools averaged 0.3 candidates per school. For instance, candidates were nominated only to two (one candidate in each) out of the 55 schools in the Akhalkalaki municipality, two schools of the Ninotsminda municipality out of the total of 33 , and two schools of the Tsalka municipality, of a total of 13 . In these regions, $79 \%$ of the candidates failed qualification exams, while another $19 \%$ were rejected after interviews. The functional writing test proved to be the main stumbling block for the candidates: most of them failed the test because of their poor knowledge of Georgian (Tabatadze, 2010 a). 
Due to the above-mentioned reasons, directors were elected only in 26 out of the 265 non-Georgian language schools of the country), namely in 16 schools of Kvemo Kartli, six schools in Tbilisi, and four schools in SamtskheJavakheti Only 10\% of non-Georgian language schools had elected school principals while the countrywide result was $53 \%$ (Tabatadze, 2010a).

In 2013, all school administrators of non-Georgian-language schools from the Akhaltsikhe district participated in the school principal certification process. Out of 14 school principals, none managed to pass certification exams.

The school principals are not prepared to design and implement bilingual education programmes. The study conducted in 2011-2012 revealed that $98.6 \%$ of the school principals have no information about the bilingual programmes in general, as well as in the context of their school. At the same time, $90 \%$ of the principals indicated that they had participated in the training related to bilingual education. This evidence once again suggests that school principals have no readiness for the implementation of the bilingual programmes despite certain professional development opportunities (Tabatadze, 2015b).

\section{The quality of bilingual school textbooks}

The problem of textbooks for minority schools seems to be one of the essential hindering factors for bilingual educational reform. In 2012, within the framework of the agreement between the Ministry of Education and Science, and publishers, one approved textbook from each subject for the $1^{\text {st }}$ to $6^{\text {th }}$ grades was translated into the Armenian, Russian and Azerbaijani languages. The translation process of textbooks has changed since 2011. According to the ministry's decision, only $70 \%$ of the material in textbooks is translated, while the remaining $30 \%$ is left in the state language. The purpose of this initiative was to promote bilingual education reform; in fact, significant problems accompanied the process of the introduction of bilingual textbooks. Specifically, the following shortcomings of the reform are identified by studies (Office of the State Minister of Georgia for Reconciliation and Civil Equality, 2014; Tabatadze, 2015c; Tabatadze, 2016):

(1) The $70 \% / 30 \%$, translation principle of textbooks was not based on any scientific evidence and did not correspond to the principles of content and language integrated learning (CLIL). Accordingly, the artificial percentile division turned out to be absolutely ineffective and to have only an adverse effect (Tabatadze, 2015c);

(2) Subject teachers who do not speak the state language are unable to use the textbooks properly since they do not understand the content of the $30 \%$ of the textbooks left in the state language (Office of the State 
Minister of Georgia for Reconciliation and Civil Equality, 2014);

(3) The parents of non-Georgian language school students were not able to assist their children in learning since they have not mastered the state language and did not understand the textbook materials (Tabatadze, 2016).

\section{Discussion of Research Results/Practical Implications}

The previous chapter of the article analysed the factors influencing the effectiveness of bilingual educational programmes in the Georgian context. In this part of the article, the possible solutions for successful implementation of the bilingual educational reform and programme will be presented and analysed on the systemic, institutional, and pedagogical levels.

\section{Systemic Bilingual Education}

Systemic bilingual educational policy implies a political level of implementing bilingual educational policies. The most important strategy on a systemic level can be the implementation of the programme in a step-by-step manner. There are two options for implementing bilingual educational policy. The first is implementing it in a step-by-step manner and the second is designing and starting implementation in all ethnic minority schools. The step-by-step policy is appropriate for the Georgian context. San Migual (2003) divides the implementation of the bilingual educational programme into two parts in the United States: voluntary and mandatory. Georgia can follow the experience of the United States and for the first stage establish voluntary bilingual education programmes and, at the same time, prepare for the second, mandatory stage.

The second important issue on a political level is that bilingual educational policy should not be an isolated policy implemented by the Ministry of Education and Science of Georgia. It should be a part of a major civil integration strategy. Local populations need specific examples of how ethnic minority students can succeed in the Georgian state. The specific examples and strategies will be the facilitation of the enrolment of ethnic minority students in higher educational institutions and the promotion of the employment of population of ethnic minorities, who master the state as well as minority languages. The specific examples and practical importance of state language acquisition are essential preconditions for the successful implementation of bilingual educational policy. Thus, bilingual educational policy should be linked to employment and economic policies. The consistency of integration policy, as well as bilingual educational reforms, is crucial. 
The third important topic on the political level is the development of a clear message about the objectives of bilingual educational policy. As Hornberger points out, bilingual education should be defined 'as a resource to be developed rather than a problem to be overcome' (2000, p. 173). Varghese (2004) distinguishes between two perceptions about bilingual education. The first is the belief that the objective of bilingual education is a transition from Native to the second language. The second is the belief that the goal of bilingual education is to achieve dual enrichment in two languages. Thus, the policy of bilingual education should clearly underline the five important goals of bilingual education proposed by Trillos (1998): ' biculturalism, or the ability to act appropriately both in the national society and in [one's] own community; bilingualism, or proficiency in more than one language; knowledge of the main values of both cultures; positive attitudes to different linguistic and cultural groups; and equality of opportunity for children from minority communities' (in Mejia, 2004, p. 394).

At the same time, bilingual education should not be 'compensatory but an enrichment program' (San Miguel, 2003, p. 30) and, thus, dominant ethnic group students can participate in it. This is especially necessary if we take into account the fact that the majority ethnic groups are in the minority in the regions compactly resided by ethnic minorities. Clarity in objectives is crucial for successful implementation of the bilingual educational programmes (Nieto, 2005).

\section{Bilingual education on the institutional level}

At the institution level, there are three essential components for the effective implementation of bilingual education: (1) school, (2), community, and (3) parental involvement in the process of both designing and implementing of the reform (Tabatadze, 2015b). The first component is school involvement in the implementation of bilingual educational policy. Opponents can argue that it is unquestionable that school should be involved as they should implement the policy. However, involvement does not mean simply an implementation of imposed bilingual educational policy. School involvement is participation in designing such policies. The first step toward the involvement of schools can be introducing the above-mentioned voluntary and mandatory stages of the implementation of bilingual educational policy. The second step is the involvement of schools in the adoption of specific bilingual models. As Mejia (2004) pointed out, it is recognised that each institution should adapt the type of bilingual education offered based on the particular context of implementations. Furthermore, it is important not to adopt 'any single model, no matter how well-tried, without the necessary modifications to specific local circumstances 
[...] merely because research background proved effectiveness' (Beardsmore, 1995, p. 140). Georgia can use the very successful experience of one of the Baltic states, where five different bilingual models were proposed by the Ministry of Education for adoption for schools. Even more, schools can develop their own models and adopt them their contexts (Hogan-Brun \& Ramoniene, 2004). The similar choice should be given to the schools in Georgia, which will increase the degree of their involvement and thus the effectiveness of the programme.

The second essential component of the effective implementation of bilingual education programmes is the involvement of local communities. The involvement of communities can be achieved by either direct management or by consultations. Local commitment can lead to democratic and relational management. Community involvement is essential for communicating the message clearly to ethnic minorities that students from ethnic minorities are offered equal chances to succeed to those of the majority of students (HoganBrun \& Ramoniene, 2004).

'Parental involvement' is the third essential component for the success of such programmes related to ethnic minority education (Swail \& Perna, 200o). On the one hand, parents are important factors for successful implementation of the programme as they can influence the profoundly political situation for bilingual education and ensure the readiness of ethnic minority students to prepare for bilingual educational programmes. On the other, parental education and involvement are part of social capital, which is necessary for ethnic minorities for success not only in education but also in their future lives (Perna $\&$ Titus, 2005). The study of Perna and Titus (2005) revealed a positive relationship between the parent involvement as social capital and ethnic minority students' educational achievements. Thus, bilingual educational programmes that can involve parents are a promising approach to addressing the problem of the non-achievement of ethnic minority students due to lack of state language proficiency. School, community, and parental involvement are crucial factors for the successful implementation of bilingual educational policy. As Nancy Hornberger pointed out 'In every case, what is needed for successful language maintenance is [...] autonomy of the speech community in deciding about the use of languages in their schools' (1987, p. 224).

\section{Bilingual Education on the pedagogical level}

Bilingual education at the pedagogical level is essential. Only schoolbased effective programmes can guarantee the success of the bilingual educational programme. On a pedagogical level, the issues of curriculum and 
textbook development, teachers training and education, effective school administration are the most crucial factors among others.

There are significant changes in educational theories about the development of curriculum, especially for bilingual schools (Mejia \& Tejada, 2003). Nowadays, more focus is made on the development of curriculum by the professionals and experts in the field, but by the practical teachers are 'more representatives of social interest and [...] process a greater capacity of real connection with the interests and needs of students in specific educational situations' (Mauri et al., 1993, p. 27 in Mejia \& Tejada, 2003). Thus, Ricento and Hornberger (1996, p. 417) recommended putting 'classroom practitioners at the heart of 'curriculum development. This assumption is especially true for the Georgian context, in which the issue of ethnic minority education is politically sensitive and requires more careful attitudes. The development of the curriculum of specific subjects should not be concentrated only in the hands of 'experts' in the field as done for the curriculum of Georgian public schools. It is better to facilitate the collaboration of experts and practitioner teachers from the region. They will balance each other, and the curriculum will reflect expertise in the field as well as social interest and local context. The culturally responsive curriculum is the second important issue for the effective development of curriculum for bilingual schools. As Smith -Madox (1998) emphasises: 'The use of culturally responsive instructional strategies changes the form and content of instruction [...] the conceptions of culture in educational practices also need to become more constructivistic and less essentialistic' (p. 313-314).

Along with the curriculum, the development of school textbooks for minority schools is an essential issue. This topic is one of the challenging issues in the Georgian context. Teachers very much depend on school textbooks in Georgian public schools. In many cases, they are the only resource for schools (Tabatadze et al., 2013). Bilingual editions of textbooks should be revised, and effective mechanisms developed in this direction. The revised textbooks should be based on the existing methodology of integration content and language teaching (Mehisto, Marsh, \& Frigols, 2008). It is also crucial to integrate native languages of national minorities as a part of the National Curriculum, and for Georgia to be aware of benchmarks in native as well as in second languages for bilingual educational reform. The development of school textbooks in minority language and literature and improvement of the quality of translation of subject textbooks into minority languages can be a significant precondition for bilingual educational reform.

Teacher's preparation and training are another essential component of bilingual education reform. As Varghese (2004, p. 223) points out 'The highly politicized and debated nature of bilingual educations serves [sic] a determining 
factor in the formation of the professional roles of bilingual teachers'. At the same time, professional roles of bilingual education teachers are influenced by societal forces created by local context and their personal life and experience (Varghese, 2004). If we take all these assumptions into account in the Georgian context, it will be clear how bilingual teacher's professional roles are complicated. Bilingual education context is very much politicised. Local societal context is complicated, as there are many local 'players', who are against bilingual educational policy. At the same time, teachers in ethnic minority schools are not bilingual (they cannot speak the state language) themselves and bilingual educational policy are additional pressure for them. They should start learning the state language to be able to teach in public schools of ethnic minorities. Thus, their personal history and experience will not be positive towards bilingual education and the formation of professional roles of bilingual educational teachers will be quite complicated in this context.

School leadership needs several essential traits and knowledge to lead bilingual programmes effectively. First, the school principal should be an instructional leader, should know curriculum approaches and language teaching methods, and should be able to deliver such approaches to the teachers (Shaw, 2003, in Baker, 2006). Being instructional leaders is directly linked to developing an effective system of school-based professional development of teachers. The research shows that school-based professional development is the most effective in comparison to other forms of teachers' professional development, such as training, lesson demonstrations or guided practice (Joyce \& Showers, 2002).

Second, school leaders should be capable administrators and managers, as they 'Not only [...] inspire, motivate, support and communicate well with staff, they also identify, secure and mobilise human, financial and material resources (Montecel \& Cortez, 2002, in Baker, 2006, p. 315). The development of a system of school principals' professional development seems essential for the Georgian context for designing and implementation of bilingual educational programmes on the pedagogical level (Tabatadze, 2010b).

\section{Conclusion}

The content analysis conducted in the framework of the study revealed significant challenges of the implementation of bilingual educational reform on the political, institutional, and pedagogical levels. Political problems of bilingual educational policy in Georgia have several crucial reasons. In Georgia, the initiative for bilingual education comes from the government, and it is mainly perceived as a violation of the educational rights of ethnic minorities by their 
representatives. One of the problems is the focus solely on teaching the state language rather than reforming minority schools. The inconsistency of the bilingual education reform is another key obstacle to the effective implementation of bilingual educational programmes on the political level. Apart from political problems, there are several on the pedagogical and institutional levels, one of which is the lack of human resources.

Despite the fact that the importance of bilingual education was recognised in the context of teaching the state language, the main purposes of bilingual education should not be ignored: to develop a balanced bilingualism in each child without causing any academic problems, and to provide the opportunity for students to receive an education in their native languages. Therefore, it is crucial that the Ministry of Education define the goals of bilingual education in Georgia to be the development of bilingualism along with the overall academic success of each student.

To achieve the goals mentioned above, curriculum and textbook reform, along with pre-service teacher education and in-service professional development reforms, should be undertaken. The latter of these will ensure the recruitment and retention of a cadre of bilingual-qualified teachers for non-Georgian language schools. The preparation of instructional leaders for these bilingual educational reforms is of the utmost importance for the successful and effective implementation of the minority educational policy in Georgia.

One essential priority must be ensuring the active involvement of the parents and community in the life of the school. Professional development of the administrators and teachers in the area of parent and community involvement will prove to be crucial to realising this priority. At the same time, the non-Georgian language schools can benefit a great deal by implementing parent-education and awareness-raising programmes. Bilingual educational policy implementation should rest on the local commitment of teachers, students, parents, and communities as a whole. Political, institutional, and pedagogical support is needed to reap the benefits of bilingual education in the Georgian context.

\section{References}

Banks, J. A., Cookson, P., Geneva, G., Hawley W.D., Irvine, ... \& Stephan G. W. (1983). Diversity Within Unity: Essential Principles for teaching and Learning in a Multicultural Society. Phi Delta Kappan, 83(3), 196-203.

Baker, C. (2006). Foundations of bilingual education and bilingualism. Clevedon, UK: Multilingual Matter. 
Batelaan, P. (2002). Bilingual education: The case of Latvia from a comparative perspective.

Intercultural Education, 3(4), 359-374

Beardsmore, B. (1995). European models of bilingual education. In O. Garcira \& C. Baker (Eds.),

Policy and practice in bilingual education (pp. 139-151). Clevedon, UK: Multilingual Matters.

Bekerman, Z. (2005). Complex contexts and ideologies: Bilingual education in conflict-ridden areas.

Journal of Language Identity and Education, 4(1), 1-20.

Beridze, M. (2013). Interrelationship of bilingual education and social-communication system in

Javakheti. International Journal of Multilingual Education, 1(2), 77-92. doi:10.22333/ijme.2013.2007

Constitution of Georgia (1995). Parliament of Georgia. Retrieved from www.parliament.ge

Crawford, J. (2000). At war with diversity. The US language policy in an age of anxiety. Clevedon, UK;

Buffalo, NY; Toronto, CA \& Sydney: Multilingual matters.

Dilāns, G., \& Zepa, B. (2015). Bilingual and multilingual education in the former Soviet Republics. In W. E. Wright, S. Boun, \& O. García (Eds.), The handbook of bilingual and multilingual education. (pp. 632-644). Malden, MA: Wiley-Blackwell.

Gabunia, K. (2014). Language situation in modern Georgia 2. Caucasian and non-caucasian languages. International Journal of Multilingual Education, 2(2), 1-21. doi:10.22333/ijme.2014.4001

Giroux, H. A. (1983). Theory and resistance in education: A pedagogy for the opposition. South Hadley,

MA: Bergin \& Garvey.

Gorgadze, N. (2016). Rethinking integration policy - Dual ethnic and cultural Identity. International Journal of Multilingual Education, 4(2), 6-31. doi: 10.22333/ijme.2016.8002

Grigule, L. (2009). Shaping the multilingual learning environment: the case of multilingual education pilot project in Georgia. Journal of Teacher Education for Sustainability, 11(1), 50-64 Haworth, P., Cullen, J., Simmons, H., Schimanski, L., McGarva, P., \& Woodhead, E. (2006). The role of acquisition and learning in young children's bilingual development: A sociocultural interpretation. International Journal of Bilingual Education and Bilingualism, 9(3), 295-309.

Hogan-Brun, G., \& Ramoniene, M. (2004). Changing levels of bilingualism across the Baltic. Bilingual Education and Bilingualism, 7(1), 62-77.

Hornberger, N. (1987). Bilingual education success, policy failure. Language in Society, 16(18), 205-226.

Hornberger, N. (2000). Bilingual education policy and practice in the Andes: Ideological paradox and intercultural possibility. Anthropology \& Education Quarterly, 31(2), 173-201.

Hornberger, N., \& Ricento, T. (1996) Unpeeling the onion: Language planning and policy and the ELT professional. TESOL Quarterly $30(3), 401-428$.

Kḷava, G., Kḷave, K., \& Motivāne, K. (2010). Latviešu valodas prasme un lietojums augstākās izglītības iestādēs: Mazākumtautību izglītības satura reformas rezultāti [Skills and use of Latvian in higher education institutions: The results of the reform of the content of minority education.] Rìga: Latviešu valodas ağentūra.

Kurbanov, Z. (2007). Interview with Zumrud Kurbanov. Newspaper Эxo, January 2007. Joyce, B. R., \& Showers B. (2002). Student achievement through staff development (3rd ed.). 
Alexandria, VA: Association for Supervision and Curriculum Development.

Lenneberg, E. H. (1967). The biological foundations of language. New York, NY: John Wiley and Sons.

Mehisto, P., Marsh, D., \& Frigols, M. (2008). Uncovering CLIL: Content and language integrated learning in bilingual and multilingual education. Oxford, UK: McMillan

Mekhuzla, S., \& Roche, A. (2009). National minorities and educational reform in Georgia. Flensburg: European Centre for Minority Issues.

Melikidze, M. (2010). Discussions on affirmative action policy in admission system of Georgia.

Retrieved from http://tolerantoba.ge/index.php?id=1314971931

Mejia, A., \& Tejada, H. (2003). Bilingual curriculum construction and empowerment in Columbia. International Journal of Bilingual Education and Bilingualism, 6(1), 37-51.

Mejia, A. (2004). Bilingual education in Columbia: Towards an integrated perspective. Bilingual Education and Bilingualism, 7(5), 381-397.

Montecel, M. R., \& Cortez, J. D. (2002). Successful bilingual education programs: Development and the dissemination of criteria to identify promising and exemplary practices in bilingual education at the national level. Bilingual Research Journal, 26(1), 1-10.

National statistics office of Georgia. (2014). Population census. Tbilisi: GeoStat. Retrieved from http://census.ge/files/results/Census\%2oRelease_GEO.pdf

Nieto, S. (2005). Public education in the twentieth century and beyond: High hopes, broken promises, and an uncertain future. Harvard Educational Review, 75(1), 1-20.

Office of the state minister of Georgia for reconciliation and civil equality (2014). Assessment document on the implementation of the national concept for tolerance and civic Integration and action plan for 2009-2012. Retrieved from http://www.smr.gov.ge/docs/doc329.pdf Ogbu, J. U. (1987). Variability in minority school performance: A problem in search of an explanation. Anthropology and Educational Quarterly, 18(4), 312-334.

Ogbu, J. U. (1991). Immigrant and involuntary minorities in comparative perspective. In J. U. Ogbu \& M. A. Gibson (Eds.), Minority status and schooling: A comprehensive study of immigrant and involuntary minorities (pp. 3-33). New York, NY: Garland Publishing.

Parliament of Georgia (2005). Law of Georgia on general education. Retrieved from www.mes.gov.ge Pavlenko, A. (2008). Multilingualism in post-Soviet countries: Language revival, language removal, and sociolinguistic theory. International Journal of Bilingual Education and Bilingualism, 11(3-4), 275-314.

Perna, L. W., \& Swail, W. S. (2000). A view of the landscape: Results of the national survey of outreach programs. In College Board, Outreach program handbook 2001 (pp. xi-xxix). New York, NY: The College Board.

Perna, L. W., \& Titus, M. (2005). The relationship between parental involvement as social capital and college enrollment: An examination of racial/ethnic group differences. Journal of Higher Education, 76(5), 485-518.

Public defenders office of Georgia (2012). Monitoring results of the implementation of the National Concept and Action Plan on Tolerance and Civil Integration in 2010-2011. Retrieved from the http:// 
www.ecmicaucasus.org/upload/cnm/UNDP-Publication-ENG-FINAL.pdf

Public defenders office of Georgia (2013). Monitoring results of the implementation of the National Concept and Action Plan on Tolerance and Civil Integration in 2012. Tbilisi: United Nations Association of Georgia.

Public Defenders Office of Georgia (2014) Monitoring results of the implementation of the National Concept and Action Plan on Tolerance and Civil Integration in 2013. Tbilisi: United Nations Association of Georgia.

Rendón, L., Jalomo, R. E., \& Nora, A. (2000). Theoretical considerations in the study of minority student retention in higher education. In C. Turner, A. L. Antonio, M. Garcia, B. V. Laden, A. Nora, \& C. L. Presley (Eds.), Racial and ethnic diversity in higher education (2nd ed.), (pp. 584-60o).

Boston: Pearson Custom Publishing.

Ricento, T. K., \& Hornberger, N. H. (1996). Unpeeling the onion: Language planning and policy and the ELT professional. Tesol Quarterly, 30(3), 401-427.

San Miguel, G. (2003). Contested Policy. The rise and fall federal bilingual education in the United States in 1960-2001. Denton, TX: University of North Texas Press, Denton.

Skutnabb-Kangas, T., \& García, O. (Eds.). (1995). Multilingualism for all? General principles. Lisse:

Swets and Zeitlinger.

Smith-Madox, R. (1998). Defining culture as a dimension of academic achievement: Implications for culturally responsive curriculum, instruction, and assessment. Journal of Negro Education, 67(3), 302-317.

Svanidze, G. (2002). National minorities in Georgia, review. Retrieved from www.minelres.lv.archive. htm

Svanidze, G. (2003). How to protect the state language? Retrieved from www.minelres.lv.archive.htm Tabatadze, S., \& Gorgadze, N. (2014) Intercultural sensitivity of primary school teachers of Georgia. International Journal on Education and Research, 2(6), 281-300.

Tabatadze, S., Gorgadze, N., Gabunia, K., Khomeriki, I., \& Tinikashvili, D. (2013) Intercultural education research in primary grades of Georgia. Tbilisi: Centre for Civil Integration and Inter-Ethnic Relations.

Tabatadze, S., \& Gorgadze, N. (2015). Minority school teacher's professional development and career growth; Policy Report. Tbilisi: Centre for Civil Integration and Inter-Ethnic Relations. Tabatadze, S., \& Gorgadze, N. (2017). Affirmative action policy in admissions system of higher education of post-Soviet Georgia. Journal of Applied Research in Higher Education, 9(3), 363-377. Tabatadze, S, (2010a). Intercultural Education in Georgia. Cultural dialogue and civil consciousness: Religious dimension of the intercultural education (pp. 63-86). Tbilisi: CIPDD Publishing. Tabatadze, S. (2010b). The Reform of Georgian educational system and non-Georgian schools. Tbilisi: Caucasus Institute for Peace, Democracy, and Development.

Tabatadze, S. (2011). Bilingual educational policy in Georgia. In K. Cushner, A. McClelland, \& P. Safford (Eds.), Human diversity in education: An Integrative Approach (pp. 282-284). New York, NY: McGrawHill. 
Tabatadze, S. (2015a). Teachers' approaches to multicultural education in Georgian classrooms. Journal for Multicultural Education, 9(4), 248-262.

Tabatadze, S. (2015b). Factors influencing the effectiveness of bilingual educational programs: The prospects of pilot programs in Georgia. Sino-US English Teaching, 12(2), 93-109.

Tabatadze, S. (2015c). Textbooks for minority schools of Georgia. Problems and challenges.

International Journal of Multilingual Education, 3(1), 1-12. doi:10.22333/ijme.2015.5001

Tabatadze, S. (2016). Minority education in Georgia: Is it delivering what is expected. Journal of

Diaspora, Minority, and Indigenous Education, 11(1), 17-30. doi: 10.1080/15595692.2016.1245658

Trillos, M. (1998). Conclusions. In M. Trillos (Ed.), Educacion Endogena Frente an Educacion Formal. Bogota: Centro Colombiano de Estudios de Lenguas Aborırgenes.

Wheatly, J. (2005). ECMI Report obstacles impeding the regional integration of the Javakheti Region of Georgia. Retrieved from http://www.ecmi.de/download/working_paper_22.pdf

Van Gennep, A. (1960). The rites of passage. Chicago, IL: University of Chicago Press.

Varghese, M.M. (200o). Bilingual teachers-in-the-making: Advocates, classroom teachers, and transients (Doctoral Dissertation). Philadelphia, PA: University of Pennsylvania.

Varghese, M. M. (2004). Professional development for bilingual teachers in the United States: A site for articulating and contesting professional roles. Bilingual Education and Bilingualism, 7(2-3), $222-238$.

\section{Biographical note}

Shalva TABatadze has a $\mathrm{PhD}$ in Education and has served as a chairman of the Centre for Civil Integration and Inter-Ethnic Relations (CCIIR) since 2005. Dr. Tabatadze is an Associate Professor at East European University. His research interests are educational policy and multilingual and intercultural education. He is the author of 4 textbooks, 7 monographs and more than 30 articles in the field of educational policy and multilingual and intercultural education and the editor of more than 10 textbooks on content and language integrated teaching. 